\title{
A microarray study of gene and protein regulation in human and rat brain following middle cerebral artery occlusion Nick Mitsios ${ }^{\dagger 1}$, Mohamad Saka ${ }^{\dagger 1}$, Jerzy Krupinski ${ }^{2}$, Roberta Pennucci ${ }^{1}$, Coral Sanfeliu' ${ }^{3}$, Qiuyu Wang1, Francisco Rubio², John Gaffney ${ }^{1}$, Pat Kumar1, Shant Kumar ${ }^{4}$, Matthew Sullivan ${ }^{1}$ and Mark Slevin*1
}

\begin{abstract}
Address: ${ }^{1}$ School of Biology, Chemistry and Health Science, John Dalton Building, Manchester Metropolitan University, Chester Street Manchester, UK, 2Department of Neurology, Stroke Unit, Hospital Universitari de Bellvitge (HUB), Fundacio IDIBELL, L' Hospitalet de Llobregat, Barcelona, Spain, ${ }^{3}$ Departamento de Farmacologia i Toxicologia, Institut d' Investigacions Biomediques de Barcelona (IIBB), CSIC-IDIBAPS, Barcelona, Spain and ${ }^{4}$ Department of Pathology, Medical School, University of Manchester and Christie Hospital, Manchester, UK

Email: Nick Mitsios - n.mitsios@mmu.ac.uk; Mohamad Saka - myassin3@hotmail.com; Jerzy Krupinski - krupinski@csub.scs.es; Roberta Pennucci - camilbea@hotmail.com; Coral Sanfeliu - cspfat@iibb.csic.es; Qiuyu Wang - q.wang@mmu.ac.uk; Francisco Rubio - frubio@cebas.csic.es; John Gaffney - j.gaffney@mmu.ac.uk; Pat Kumar - p.kumar@mmu.ac.uk; Shant Kumar - shant.kumar@man.ac.uk; Matthew Sullivan - m.sullivan@mmu.ac.uk; Mark Slevin* - m.a.slevin@mmu.ac.uk * Corresponding author †Equal contributors
\end{abstract}

Published: 12 November 2007

BMC Neuroscience 2007, 8:93 doi:10.1186/1471-2202-8-93

This article is available from: http://www.biomedcentral.com/I47I-2202/8/93

(C) 2007 Mitsios et al; licensee BioMed Central Ltd.

This is an Open Access article distributed under the terms of the Creative Commons Attribution License (http://creativecommons.org/licenses/by/2.0), which permits unrestricted use, distribution, and reproduction in any medium, provided the original work is properly cited.
Received: 4 April 2007

Accepted: 12 November 2007

\begin{abstract}
Background: Altered gene expression is an important feature of ischemic cerebral injury and affects proteins of many functional classes. We have used microarrays to investigate the changes in gene expression at various times after middle cerebral artery occlusion in human and rat brain.

Results: Our results demonstrated a significant difference in the number of genes affected and the time-course of expression between the two cases. The total number of deregulated genes in the rat was 335 versus 126 in the human, while, of 393 overlapping genes between the two array sets, 184 were changed only in the rat and 36 in the human with a total of 4 I genes deregulated in both cases. Interestingly, the mean fold changes were much higher in the human. The expression of novel genes, including P2I-activated kinase I (PAKI), matrix metalloproteinase II (MMPII) and integrase interactor I, was further analyzed by RT-PCR, Western blotting and immunohistochemistry. Strong neuronal staining was seen for PAKI and MMPII.

Conclusion: Our findings confirmed previous studies reporting that gene expression screening can detect known and unknown transcriptional features of stroke and highlight the importance of research using human brain tissue in the search for novel therapeutic agents.
\end{abstract}

\section{Background}

Ischaemic stroke results from obstruction of blood flow in a major cerebral vessel and leads to deregulation of genes whose expression promotes ischemic neuronal death and subsequent neurological dysfunction [1,2]. Under ischemic conditions, energy metabolism fails, and severe reduction in mRNA and protein synthesis occurs in the ischemic core region. The tissue surrounding this area (peri-infarcted region) is able to maintain some functions, such as ionic homeostasis and can be partially salvaged by blood recirculation $[3,4]$. 
The precise molecular mechanisms involved in ischemiainduced brain injury remain poorly understood. Limited knowledge of the molecular mechanisms involved in tissue regeneration has been gained from animal experiments using the middle cerebral artery occlusion (MCAO) model which replicates, in many aspects, the neuropathological changes following stroke in humans [5]. Although the contralateral side of the brain is not totally unaffected by ischemic damage, the collection of experimental and reference control tissue from the same animal is a better comparison than using sham-operated control in rats, while in human samples the only control tissue available is contralateral hemisphere. In addition, using contralateral tissue as a control and the direct comparison with stroke hemisphere provides the best model for validation as it removes inter-patient genetic variation and also minimises the differences in potential degradation between the target and reference mRNAs. This has been applied previously in both human [6,7] and animal [8-10] studies. Rao et al. in particular observed very few differences in gene expression between sham and contralateral cortex at $24 \mathrm{~h}$ of reperfusion following MCAO in the rat [9].

Analysis of ischemic brain tissue with techniques capable of studying multiple transcripts simultaneously can identify gene expression changes previously not known to be implicated in ischemic pathophysiology and may lead to development of new targets for stroke therapy [11]. DNA microarray technology has been used to investigate the expression of thousands of genes in a single hybridization experiment. Several experimental studies have examined alteration of gene expression in the postischemic rat brain using microarray technology [8-10,12-18], while blood genomic profiling in human stroke have been investigated in recent pilot studies $[19,20]$ (Table 1 ). Critical comparison of gene expression profiles after stroke in humans with those in animal models may lead to a better understanding of the pathophysiology of brain ischaemia and allow an evaluation of the usefulness of animal models in stroke research.

Until recently, gene expression profiling had not been applied to patients dying of ischemic stroke, in part because human brain autopsies are not regularly obtained. Although tissue obtained from brain autopsies is generally of lower quality than that of brain biopsies obtained from living patients, the majority of RNA transcripts and proteins in the human brain are reasonably stable (compared to other tissues such as blood and kidney) and degrade to only a minor degree following death, thus making autopsy tissue a useful source for the isolation of nucleic acids and proteins [21]. Previous studies evaluating the mRNA quality in human post-mortem brain tissue have demonstrated a minimal effect upon their overall relative stability and indicated that frozen brains up to 72 hours post-mortem can be efficiently analyzed [22]. In line with that, in previous human brain studies, tissue was obtained up to a maximum of 6 hours [7], 40 hours [23], 45 hours [24] and 69 [6] hours following death. Moreover, after comparing mRNA levels in autopsies and biopsies, Castensson et al. [25] found a general similarity in the levels between the two groups, and suggested that mRNA levels in brain autopsy samples can provide clues about the brain in vivo. Interestingly, Almeida et al. [26] found that, even if performed on degraded RNA, RT-PCR can be used to provide a reliable estimate of in vivo mRNA levels, maybe due to the similarities in the rates of degradation between the target and reference mRNAs. Recently, Vikman and Edvinsson [27] investigated the gene expression in human brain after ischaemia using samples 7-10 days post-stroke; however, they obtained their samples after a considerable delay of 2-3 days post-mortem and they focused mainly on mRNA expression of receptors.

To identify the genes whose expression was changed in the human brain following ischaemia, we investigated the dynamic changes in gene expression in brain samples (collected within $6 \mathrm{~h}$ of death) from patients with various times of survival (2-37 days; Table 2) following stroke and compared them with those at various time-points (1 hour - 21 days) following middle cerebral artery occlusion (MCAO) in rats. The Atlas 1.2 cDNA microarray was used to screen for differential expression of 1176 genes and significantly de-regulated genes were selected through image analysis. We further investigated whether the altered mRNA and protein levels of a subset of deregulated molecules in the postischemic brain could be reproduced in an in vitro model of neuronal and endothelial cell culture under conditions of oxygen-glucose deprivation (OGD). The findings confirmed previous studies reporting that parallel screening of gene expression can detect both previously documented and novel transcriptional features of the cerebral response to ischemia, and demonstrated significant differences in gene expression between human stroke and the animal model.

\section{Results \\ cDNA microarray analysis}

The expression of ischemia-related genes was determined by comparing the infarct-induced expression (combined samples from infarcted and peri-infarcted areas) to that in the contralateral hemisphere: 77, 92 and 15 genes were de-regulated in stroke-affected regions in the 3 patient survival groups respectively, while 9, 51, 48, 166, 253, 117 and 261 genes were altered at the 7 different time-points in the animal model compared to the controls (Figure 1). The combined number of differentially expressed transcripts in stroke patients represented 6.5\%, 7.8\% and $1.3 \%$ respectively in each survival group of the total 
m Table I: Previous studies employing microarray approaches to study stroke

\begin{tabular}{|c|c|c|c|c|c|c|c|c|c|c|c|c|c|c|}
\hline & $\begin{array}{l}\text { Soriano et al. } \\
2000\end{array}$ & Jin et al. 2001 & $\begin{array}{l}\text { Kim et al. } \\
2002\end{array}$ & Rao et al. 2002 & $\begin{array}{l}\text { Schmidt- } \\
\text { Kastner et } \\
\text { al. } 2002\end{array}$ & $\begin{array}{l}\text { Tang et al. } \\
2002\end{array}$ & $\begin{array}{l}\text { Roth et al. } \\
2003\end{array}$ & Kim et al. 2004 & $\begin{array}{l}\text { Lu et al. } \\
2004\end{array}$ & Moore et al. 2005 & $\begin{array}{l}\text { Ford et al. } \\
2006\end{array}$ & $\begin{array}{l}\text { Tang et al. } \\
2006\end{array}$ & $\begin{array}{l}\text { Vikman and } \\
\text { Edvinsson } 2006\end{array}$ & Our data \\
\hline $\begin{array}{l}\text { Material } \\
\text { used }\end{array}$ & $\begin{array}{l}\text { Rat brain } \\
\text { tissue }\end{array}$ & Rat brain tissue & $\begin{array}{l}\text { Rat brain } \\
\text { tissue }\end{array}$ & Rat brain tissue & $\begin{array}{l}\text { Rat brain } \\
\text { tissue }\end{array}$ & $\begin{array}{l}\text { Rat brain } \\
\text { tissue }\end{array}$ & $\begin{array}{l}\text { Rat brain } \\
\text { tissue }\end{array}$ & Rat brain tissue & $\begin{array}{l}\text { Rat brain } \\
\text { tissue }\end{array}$ & & $\begin{array}{l}\text { Rat brain } \\
\text { tissue }\end{array}$ & & & \\
\hline $\begin{array}{l}\text { Model of } \\
\text { ischemia }\end{array}$ & $\begin{array}{l}\text { Permanent } \\
\text { focal MCAO }\end{array}$ & $\begin{array}{c}\text { Transient } \\
\text { global MCAO }\end{array}$ & $\begin{array}{l}\text { Permanent } \\
\text { focal } \\
\text { MCAO }\end{array}$ & $\begin{array}{l}\text { Transient focal } \\
\text { MCAO }\end{array}$ & $\begin{array}{l}\text { Transient } \\
\text { focal } \\
\text { MCAO }\end{array}$ & $\begin{array}{l}\text { Permanent } \\
\text { focal } \\
\text { MCAO }\end{array}$ & $\begin{array}{l}\text { Permanent } \\
\text { focal MCAO }\end{array}$ & $\begin{array}{l}\text { Transient focal } \\
\text { MCAO }\end{array}$ & $\begin{array}{c}\text { Transient } \\
\text { focal } \\
\text { MCAO }\end{array}$ & $\begin{array}{l}\text { Blood from } \\
\text { ischemic stroke } \\
\text { patients }\end{array}$ & $\begin{array}{l}\text { Permanent } \\
\text { and } \\
\text { transient } \\
\text { focal } \\
\text { MCAO }\end{array}$ & $\begin{array}{l}\text { Blood from } \\
\text { ischemic } \\
\text { stroke } \\
\text { patients }\end{array}$ & $\begin{array}{l}\text { Post-mortem } \\
\text { brain tissue } \\
\text { from II stroke } \\
\text { patients }\end{array}$ & $\begin{array}{c}\text { Post-mortem } \\
\text { brain tissue } \\
\text { from } 12 \\
\text { stroke } \\
\text { patients and } \\
\text { permanent } \\
\text { focal rat } \\
\text { MCAO }\end{array}$ \\
\hline $\begin{array}{l}\text { No of } \\
\text { genes }\end{array}$ & 750 & 374 & 1176 & 1263 & 9044 & $\sim 8,000$ & $\sim 13,000$ & 5,000 & 1,322 & $\sim 19,000$ & 8784 & $\sim 39,000$ & 7458 & 1176 \\
\hline $\begin{array}{l}\text { Time after } \\
\text { ischemia }\end{array}$ & 3 hours & $\begin{array}{l}4 \text { hours } \\
24 \text { hours } \\
72 \text { hours }\end{array}$ & 6 hours & $\begin{array}{l}6 \text { hours } \\
24 \text { hours }\end{array}$ & 5 hours & 24 hours & $\begin{array}{l}1 \text { hours } \\
3 \text { hours } \\
6 \text { hours } \\
24 \text { hours }\end{array}$ & $\begin{array}{l}3 \text { hours } \\
6 \text { hours } \\
12 \text { hours } \\
1 \text { days } \\
2 \text { dyss } \\
4 \text { days }\end{array}$ & $\begin{array}{l}30 \text { min } \\
4 \text { hours } \\
8 \text { hours } \\
24 \text { hours } \\
3 \text { days } \\
7 \text { days }\end{array}$ & $\begin{array}{l}\text { As soon as possible } \\
\text { after hospitalization }\end{array}$ & 24 hours & $\begin{array}{l}3 \text { hours } \\
5 \text { hours } \\
24 \text { hours }\end{array}$ & $\begin{array}{l}\text { 7-10 days } \\
\text { (obtained 2-3 } \\
\text { days post- } \\
\text { mortem) }\end{array}$ & $\begin{array}{l}\text { I hour-2I } \\
\text { days (rat) and } \\
2-37 \text { days } \\
\text { (human, } \\
\text { obtained by } 6 \\
\text { hours post- } \\
\text { mortem) }\end{array}$ \\
\hline $\begin{array}{l}\text { Cut-off } \\
\text { values }\end{array}$ & 2.0 -fold & 1.7 -fold & 2.0 -fold & 2.5 -fold & 1.7 -fold & 2.0 -fold & 3.0 -fold & 2.0 -fold & 2.0 -fold & - & 2.0 -fold & 1.5 -fold & - & 2.0 -fold \\
\hline $\begin{array}{l}\text { Confirmat } \\
\text { ion of } \\
\text { results }\end{array}$ & $\begin{array}{l}\text { In situ } \\
\text { hybridization, } \\
\text { western } \\
\text { blotting }\end{array}$ & $\begin{array}{c}\text { Western } \\
\text { blotting, } \\
\text { immuno- } \\
\text { histochemistry }\end{array}$ & RT-PCR & $\begin{array}{l}\text { Real-time PCR, } \\
\text { antisense } \\
\text { knockdown, } \\
\text { western } \\
\text { blotting, } \\
\text { immuno- } \\
\text { histochemistry }\end{array}$ & $\begin{array}{l}\text { Microarray } \\
\text { analysis } \\
\text { only }\end{array}$ & $\begin{array}{l}\text { Real-time } \\
\text { RT-PCR }\end{array}$ & $\begin{array}{l}\text { Cell culture, } \\
\text { in situ } \\
\text { hybridization, } \\
\text { western } \\
\text { blotting, } \\
\text { immuno- } \\
\text { fluorescence }\end{array}$ & $\begin{array}{l}\text { Cell culture, } \\
\text { northern } \\
\text { blotting, RT- } \\
\text { PCR, western } \\
\text { blotting, } \\
\text { immuno- } \\
\text { histochemistry }\end{array}$ & $\begin{array}{l}\text { Real-time } \\
\text { RT-PCR }\end{array}$ & $\begin{array}{l}\text { Real-time } \\
\text { RT-PCR }\end{array}$ & $\begin{array}{l}\text { Microarray } \\
\text { analysis } \\
\text { only }\end{array}$ & $\begin{array}{l}\text { Microarray } \\
\text { analysis } \\
\text { only }\end{array}$ & $\begin{array}{l}\text { Real-time PCR, } \\
\text { immuno- } \\
\text { histochemistry }\end{array}$ & $\begin{array}{l}\text { Cell culture, } \\
\text { RT-PCR, } \\
\text { western } \\
\text { blotting, } \\
\text { immuno- } \\
\text { histochemistr } \\
\text { y, immuno- } \\
\text { fluorescence }\end{array}$ \\
\hline $\begin{array}{l}\text { Selected } \\
\text { molecules }\end{array}$ & $\begin{array}{l}\text { NGFI-C } \\
\text { ARC }\end{array}$ & $\begin{array}{l}\text { GRB2 } \\
\text { SMNI }\end{array}$ & $\begin{array}{l}\text { IFN-IP } \\
\text { NDGAP-I } \\
\text { NPR }\end{array}$ & SOCS-3 & & $\begin{array}{l}\text { NARP } \\
\text { SPR } \\
\text { SPIN2C } \\
\text { ARGI } \\
\text { LBP }\end{array}$ & PC4 & FAK & $\begin{array}{l}\text { Synaptic } \\
\text { proteins }\end{array}$ & $\begin{array}{c}\text { CDI4 } \\
\text { CD36 } \\
\text { FCGR2A } \\
\text { IFNGRI caspase-I } \\
\text { a-catenin }\end{array}$ & & & $\begin{array}{l}\text { LY64 } \\
\text { ELK3 } \\
\text { POU3F4 } \\
\text { RHOA }\end{array}$ & $\begin{array}{l}\text { PAKI } \\
\text { MMPII } \\
\text { INII }\end{array}$ \\
\hline
\end{tabular}


§ु Table 2: Clinical Details of Patients

\begin{tabular}{|c|c|c|c|c|c|c|c|c|c|c|c|c|c|c|}
\hline Patient no. & Age/sex & $\begin{array}{c}\text { Survival } \\
\text { after } \\
\text { stroke }\end{array}$ & $\begin{array}{l}\text { NIHSS on } \\
\text { admission }\end{array}$ & Hypertension ${ }^{\mathrm{a}}$ & $\begin{array}{c}\text { Coronary } \\
\text { artery } \\
\text { disease }\end{array}$ & $\begin{array}{c}\text { Atrial } \\
\text { fibrillation }\end{array}$ & $\begin{array}{c}\text { History of } \\
\text { TIA } \\
\text { previous } \\
\text { stroke }\end{array}$ & Hypercholesterolemia ${ }^{b}$ & Smoking & Obesityc & Cause of death & Antiplatelets & Statins $^{d}$ & RSA-be \\
\hline I & $63 / F$ & 2 days & 26 & Yes & No & No & No & No & No & No & $\begin{array}{l}\text { Large ischemic } \\
\text { stroke }\end{array}$ & No & No & Yes \\
\hline 2 & $84 / M$ & 3 days & 21 & Yes & Yes & No & No & No & Yes & No & Malignant stroke & No & No & No \\
\hline 3 & $68 / M$ & 3 days & 24 & Yes & Yes & No & No & Yes & No & No & Brain oedema & No & No & Yes \\
\hline 4 & $84 / M$ & 6 days & 22 & Yes & Yes & No & No & No & No & No & Cardiac failure & Yes & Yes & No \\
\hline 5 & $51 / M$ & 9 days & 25 & Yes & No & No & Yes & No & No & No & $\begin{array}{c}\text { Respiratory } \\
\text { infection }\end{array}$ & Yes & No & No \\
\hline 6 & $74 / M$ & 15 days & 22 & Yes & Yes & No & No & No & No & Yes & Heart attack & Yes & No & Yes \\
\hline 7 & $86 / M$ & 15 days & 14 & Yes & Yes & No & No & Yes & No & No & Urinary infection & Yes & No & No \\
\hline 8 & $58 / M$ & 17 days & 16 & Yes & Yes & No & No & Yes & Yes & No & Cardiac infarction & Yes & No & No \\
\hline 9 & $74 / M$ & 20 days & 12 & Yes & Yes & No & No & No & No & No & $\begin{array}{l}\text { Bronchial } \\
\text { aspiration }\end{array}$ & Yes & No & No \\
\hline 10 & $73 / M$ & 26 days & 14 & Yes & Yes & No & No & Yes & No & Yes & $\begin{array}{l}\text { Respiratory } \\
\text { infection }\end{array}$ & Yes & No & Yes \\
\hline 11 & $75 / M$ & 29 days & 20 & No & Yes & Yes & No & No & Yes & No & Septic shock & Yes & No & Yes \\
\hline 12 & $60 / F$ & 37 days & 18 & Yes & Yes & No & No & Yes & Yes & No & $\begin{array}{l}\text { Pulmonary } \\
\text { embolism }\end{array}$ & Yes & No & No \\
\hline
\end{tabular}

a Blood pressure greater than $135 / 85 \mathrm{mmHg}$.

b Serum total cholesterol levels greater than $5.2 \mathrm{mmol}$.

c Body mass index greater than 30.

d Patients who were on statins before the ischemic stroke.

e Patients taking either angiotensin converting enzyme inhibitors or angiotensin type I receptor antagonists.

$M=$ male; $F=$ female; NIHSS = NIH Stroke Scale; TIA = Transient Ischaemic Attack. 
A

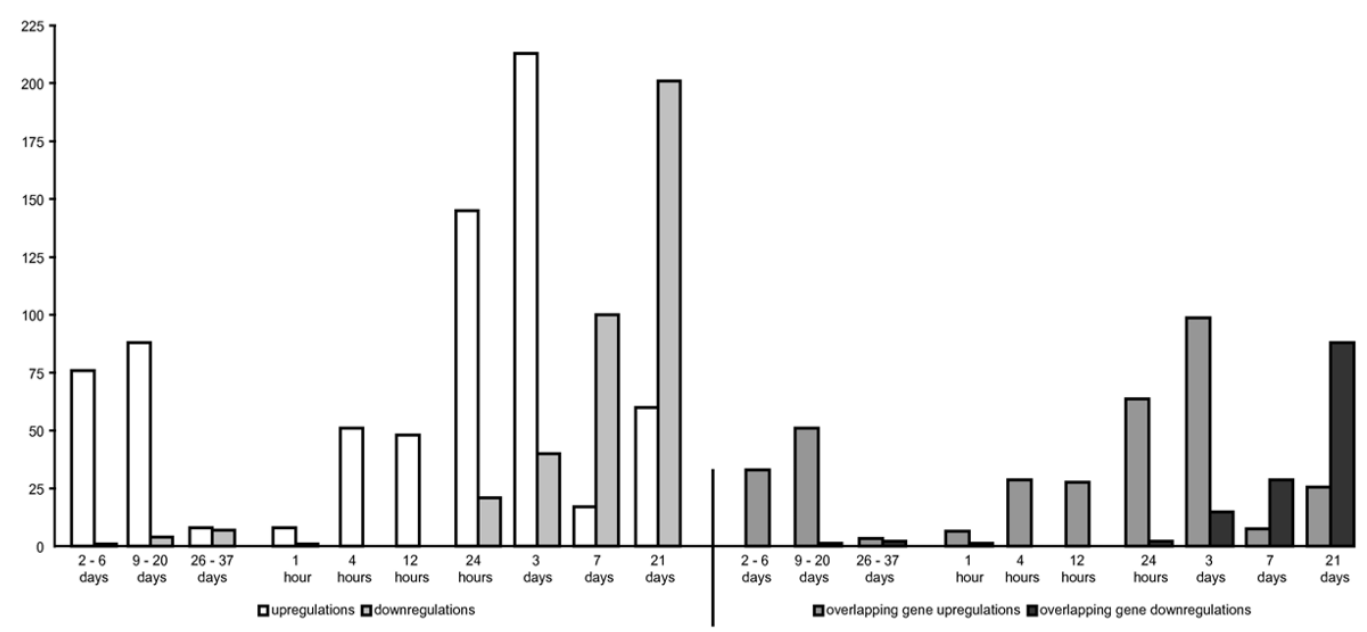

B
2-6 days
9-20 days
26-37 days
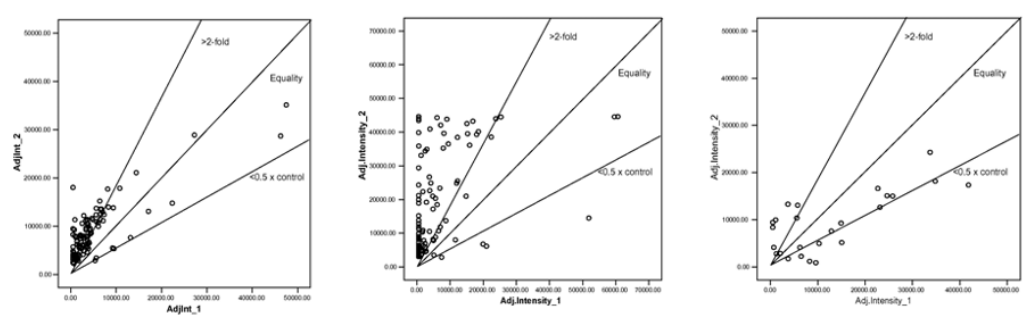

C
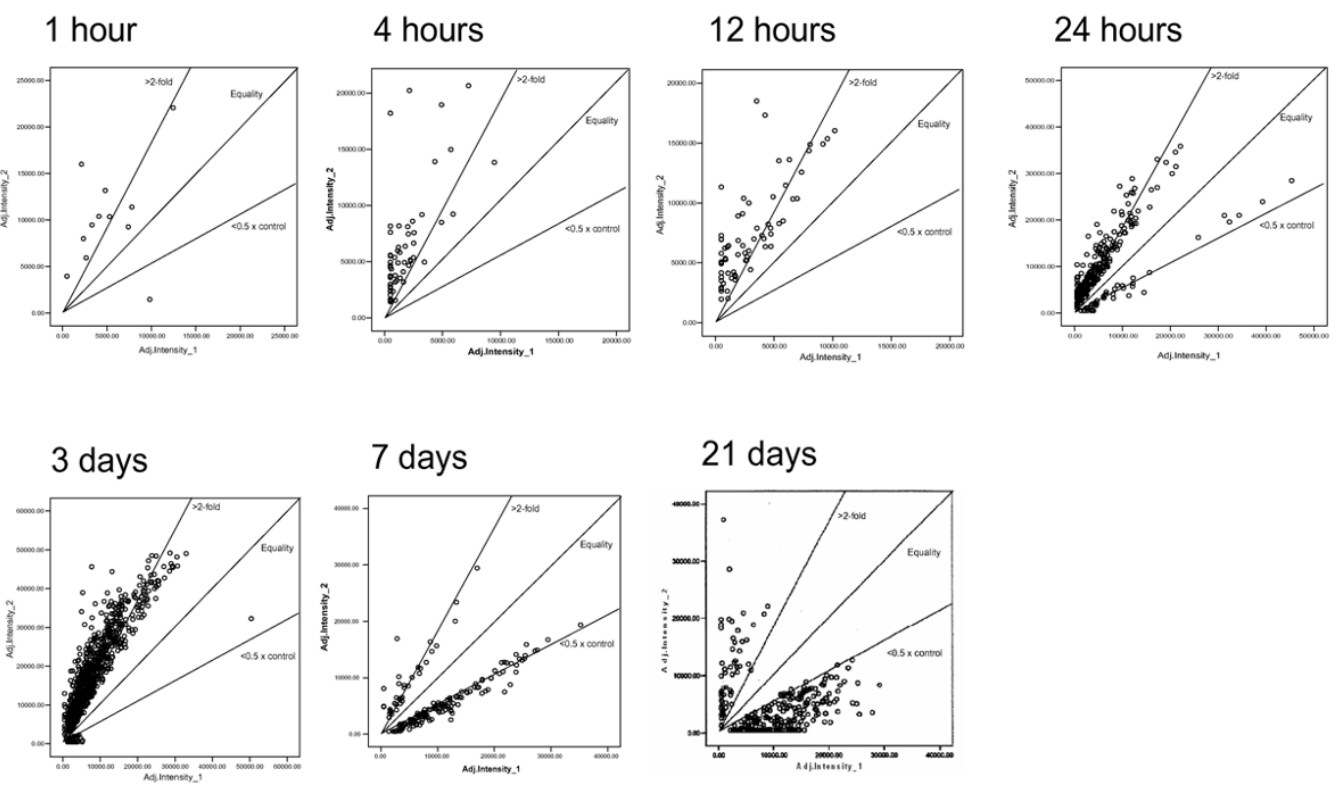

21 days

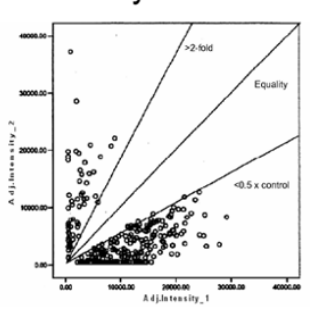

Figure I

Statistical analysis of microarray data. Total number of genes and number of overlapping genes (between the two array sets) deregulated following stroke in human and rat (A). Scatter plots representing the data dispersion over two logarithmic scales for all time-points in human (B) and rat (C). 
number of the genes on the microarray. These findings compare with $0.8 \%, 4.3 \%, 4 \%, 14.1 \%, 21.5 \%, 10 \%$ and $22.2 \%$ of genes respectively at each time-point in rats.

In total, 126 genes were deregulated after stroke in humans and 335 in the rat MCAO model. However, these data are not directly comparable since many transcripts in the human array were not present in the rat array and vice versa. Out of a total of 393 genes present in both arrays, 31,49 and 5 showed deregulated expression in the 3 patient groups respectively, whilst 7, 27, 26, 62, 107, 34 and 107 genes were deregulated at each of the 7 timepoints respectively following rat MCAO (Table 3, Figure 1). Of the 393 overlapping transcripts, the expression of 36 was changed only in the human study, compared with 184 that were altered only in the animal model, while only 41 deregulated genes were shared between the two studies. Interestingly, the mean fold changes in the human data were much higher than in the rat.

Amongst these genes we examined in more detail a small subset with no prior report of a role in stroke (PAK1, MMP11 and INI1). PAK1 was only induced in the human study although present in both microarray sets, MMP11 was induced in both cases, while INI1 was induced in the human but was not present in the rat microarray set. To confirm the microarray data, RT-PCR was carried out on selected deregulated genes. The temporal expression patterns of these genes following RT-PCR showed good agreement with the corresponding expression profiles obtained from the microarray analysis, supporting the validity of the data obtained from the microarrays. Using Western blotting and immunohistochemistry, PAK1, INI1 and MMP11 protein expression and localization was determined in the contralateral and ipsilateral brain areas of individual stroke patients and rats subjected to MCAO, and in HBMEC and HFN exposed to OGD and reperfusion.

\section{Integrase Interactor I (INII)}

In agreement with the microarray data, RT-PCR demonstrated an increase in ini1 mRNA levels in peri-infarcted and infarcted areas of patients who survived between 2 and 6 days following stroke (Figure 2A). Analysis of INI1 protein expression in samples from individual stroke patients showed that protein levels were increased in periinfarcted and infarcted regions in 8 of 12 samples (Table 4; Figure 2Bi and 2Bii). Only one patient who survived for 3 days after stroke showed decreased protein expression. Cells from contralateral white matter were not stained for INI1 but some weak neuronal cytoplasmic staining was seen in grey matter (Figure 2Ci). An increase in its expression was observed in the cytoplasm of cells with the morphological appearance of glia and microvessels from periinfarcted and infarcted areas of patients surviving for 3 to
29 days after stroke (Figure 2Cii and 2Ciii). In the rat, RTPCR and Western blotting demonstrated no notable changes in INI1 mRNA and protein expression respectively following MCAO. Weak cytoplasmic staining was observed in contralateral neurons but no differences in the level of INI1 neuronal expression occurred following MCAO (data not included). Finally, HFN and HBMEC exposed to OGD and/or reperfusion showed no difference in mRNA and protein levels for INI1 when compared with untreated cells.

\section{Matrix Metalloproteinase II (MMPII)}

For MMP11, RT-PCR data agreed with the findings from the microarray study, showing increased mRNA levels in infarcted and peri-infarcted tissue from patients surviving 2-20 days following stroke (Figure 3Ai). Western blotting in individual patient samples demonstrated that 6 of 12 patients had elevated MMP11 protein levels (Table 4; Figure 3Bi and 3Bii). The majority of cells from contralateral grey and white matter were not stained for MMP11 (Figure $3 \mathrm{Ci}$ ). In patients surviving from 3 days to 4 weeks, endothelial cells and neurons from both infarcted and peri-infarcted tissue were stained positive for MMP11 (Figure 3Cii and 3Ciii). In the rat model, RT-PCR confirmed the microarray data for some of the time-points, showing no notable change in mRNA levels at 1 and $12 \mathrm{~h}$ but a prolonged upregulation at 3 days following MCAO (Figure 3Aii). Protein levels were elevated at $1 \mathrm{~h}, 24 \mathrm{~h}$ and 3 days, after which they returned to control levels. No staining for MMP11 was seen in contralateral areas (Figure 3Di), but an increase in its expression occurred in neurons following $\mathrm{MCAO}$, in particular at 12 and $24 \mathrm{~h}$ (Figure 3Dii). MMP11 mRNA and protein levels remained unchanged in HFN and HBMEC exposed to conditions of oxygen-glucose deprivation.

\section{P2 I-activated kinase I (PAKI)}

RT-PCR confirmed the upregulation of pak1 determined by the microarrays in pooled samples from stroke patients who survived between 2 and 6 days following stroke (Figure $4 \mathrm{~A}$ ). Western blotting showed an upregulation in the protein levels of PAK1 in 6 of 12 patients (Table 4; Figure $4 \mathrm{Bi}$ and $4 \mathrm{Bii}$ ). No staining was seen in contralateral white matter, while, in grey matter, PAK1 stained weakly the cytoplasm of some neurons (Figure $4 \mathrm{Di}$ ). In patients surviving for 3 days to 4 weeks after stroke, increased PAK1 nuclear staining was seen in neurons in both peri-infarcted and infarcted regions (Figure 4Dii). In the rat, RTPCR showed no significant changes in the mRNA levels for pak1 at most of the time-points examined. However, Western blotting showed an upregulation in protein levels 1,12 and $24 \mathrm{~h}$ after MCAO, returning to control levels at 3 days, and becoming downregulated at 7 days following MCAO (Figure 4Ci and 4Cii). Weak staining was observed in neurons from the contralateral hemisphere (Figure 
Table 3: Genes deregulated in both human and animal stroke microarrays

\begin{tabular}{|c|c|c|c|c|c|c|c|c|}
\hline \multirow[b]{2}{*}{ Gene name } & \multicolumn{2}{|c|}{ Human } & \multicolumn{2}{|c|}{ Rat } & \multicolumn{2}{|c|}{ Human } & \multicolumn{2}{|c|}{ Rat } \\
\hline & GenBank & SwissProt & GenBank & SwissProt & Max/min & Days & Max/min & Time \\
\hline c-jun proto-oncogene & 104111 & $\underline{P 05412}$ & $\underline{X 17163}$ & $\underline{\mathrm{PI} 7325}$ & 4.4-fold & $9-20$ & 3.5-fold & $\mathrm{l} h-24 \mathrm{~h}$ \\
\hline Matrix metalloproteinase II & $\underline{\times 57766}$ & $\underline{\mathrm{P} 24347}$ & $\underline{\cup 46034}$ & P97568 & 3.2-fold & $2-20$ & 2.6-fold & 3 days \\
\hline \multirow[t]{2}{*}{ Calcium/calmodulin-dependent kinase (CAMKI) } & $\underline{\mathrm{L} 41816}$ & $\mathrm{Q} 14012$ & $\underline{\mathrm{L} 24907}$ & Q63450 & I7.2-fold & $2-20$ & 0.05 -fold & 21 days \\
\hline & & & $\underline{\mathrm{L} 26288}$ & Q63084 & & & & \\
\hline \multirow[t]{2}{*}{ LIM domain kinase I } & D26309 & $\underline{\text { P53667 }}$ & $\underline{\mathrm{D} 31873}$ & P53669 & 3.6-fold & $2-20$ & 2.4-fold & 3 days \\
\hline & & & & & & & 0.4-fold & 21 days \\
\hline T-Lymphocyte maturation-associated protein & MI5800 & $\underline{\mathrm{P} 2|| 45}$ & $\underline{\mathrm{U}} 1367$ & Q64349 & I.7-fold & $2-6$ & 0.2 -fold & 21 days \\
\hline \multirow[t]{2}{*}{ Retinoic Acid Receptor beta } & $\underline{M 84820}$ & $\underline{\mathrm{P} 28702}$ & $\underline{M 81766}$ & $\underline{\mathrm{P} 49743}$ & 2.0 -fold & $2-6$ & 0.1 -fold & 21 days \\
\hline & S54072 & $\underline{\mathrm{P} 28703}$ & & & & & & \\
\hline Tyrosine Phosphatase IB & M31724 & $\underline{\mathrm{P} \mid 8031}$ & M33962 & $\underline{P 20417}$ & 3.4-fold & $2-6$ & 0.2 -fold & 21 days \\
\hline Adenosine AI Receptor & $\underline{\mathrm{S} 56 \mid 43}$ & P30542 & M64299 & $\underline{\mathrm{P} 25099}$ & 2.6-fold & $2-6$ & 5.2-fold & $4 \mathrm{hrs}$ \\
\hline \multirow[t]{2}{*}{ Growth arrest \& DNA damage-inducible I53 } & $\underline{S 40706}$ & P35638 & $\underline{\mathrm{U}} 30186$ & $\underline{062804}$ & 2.4-fold & $2-6$ & 2.1-fold & 3 days \\
\hline & $\underline{S 62138}$ & & & & & & & \\
\hline Glutamate Decarboxylase 67 & $\underline{M 81883}$ & $\underline{099259}$ & $\underline{M 34445}$ & $\underline{\mathrm{P} 18088}$ & 5.6-fold & $2-6$ & 2.5 -fold & 21 days \\
\hline Glutamate Decarboxylase 65 & M81882 & $\underline{099259}$ & $\underline{M 72422}$ & $\underline{005683}$ & 22.7-fold & $2-20$ & 2.2-fold & 3 days \\
\hline Neurotrophin 3 & $\underline{M 37763}$ & $\underline{\mathrm{P} 20783}$ & $\underline{M 34643}$ & $\underline{\mathrm{P} 18280}$ & 5.I-fold & $2-37$ & 2.2 -fold & $12 \mathrm{hrs}$ \\
\hline Inhibitor of DNA binding 2 & M97796 & $\underline{002363}$ & D10863 & $\underline{\mathrm{P} 41137}$ & 5.6-fold & $2-20$ & 0.4-fold & 21 days \\
\hline Neuropeptide $Y$ & $\underline{\mathrm{K}} 01911$ & $\underline{\mathrm{P} 01303}$ & $\underline{M 20373}$ & $\underline{\mathrm{P} 07808}$ & 8.8-fold & $2-20$ & 0.04 -fold & 21 days \\
\hline Glia Maturation Factor beta & $\underline{M 86492}$ & $\underline{\mathrm{P} I 7774}$ & $\underline{Z 1 \mid 558}$ & $\underline{063228}$ & 7.6-fold & $2-6$ & 0.04 -fold & 21 days \\
\hline \multirow[t]{2}{*}{ High Mobility Group Protein I } & M23619 & $\underline{\mathrm{P} 17096}$ & $\underline{M 64986}$ & $\underline{\mathrm{P} 27109}$ & 4.3-fold & $2-37$ & 3-fold & $4 h-3 d$ \\
\hline & & & & $\underline{\mathrm{P} 27428}$ & & & 0.3 -fold & 21 days \\
\hline \multirow[t]{2}{*}{ Early Growth Response Protein I } & $\times 52541$ & $\underline{\mathrm{P} 18146}$ & M18416 & P08154 & 4.4-fold & $2-20$ & 3.9-fold & $\mathrm{Ih}-12 \mathrm{~h}$ \\
\hline & M62829 & & 104154 & & & & 0.2 -fold & 21 days \\
\hline TAT-Binding Protein I & M34079 & $\underline{\mathrm{P} I 7980}$ & $\underline{U} 77918$ & $\underline{\mathrm{P} 97638}$ & 3.8-fold & $2-20$ & 0.4-fold & 21 days \\
\hline Glutathione S-Transferase I & 103746 & $\underline{P 10620}$ & 103752 & $\underline{P 0801 I}$ & I7.5-fold & $2-20$ & 10.8-fold & $24 \mathrm{~h}-21 \mathrm{~d}$ \\
\hline \multirow[t]{3}{*}{ Fibroblast Growth Factor Receptor I } & $\underline{M 63887}$ & $\underline{Q 02063}$ & D12498 & $\underline{0} 04589$ & 10.1-fold & $2-20$ & 4-fold & $4 h-24 h$ \\
\hline & M63888 & Q02065 & & & & & & \\
\hline & M63889 & & & & & & & \\
\hline \multirow[t]{2}{*}{ Interleukin 10} & $\underline{M 57627}$ & $\underline{\mathrm{P} 22301}$ & $\underline{\mathrm{L} 02926}$ & $\underline{\mathrm{P} 29456}$ & 2.4-fold & $2-2026-37$ & 6.4-fold & 21 days \\
\hline & & & & Q63263 & 0.2 -fold & & & \\
\hline Heat Shock Protein 27 & $\underline{\times 54079}$ & $\underline{\mathrm{P}} 04792$ & M86389 & $\underline{\mathrm{P}} 42930$ & 0.6 -fold & $2-20$ & 15.2-fold & $4 h-24 h$ \\
\hline \multirow[t]{2}{*}{ Heat Shock Protein 70} & $\underline{M 11717}$ & P08107 & $\underline{Z 27118}$ & $\overline{Q 63718}$ & 0.6 -fold & $2-6$ & 9.4-fold & $\mathrm{I} h-24 \mathrm{~h}$ \\
\hline & & $\underline{P 19790}$ & & & & & & \\
\hline \multirow[t]{2}{*}{ Thioredoxin Peroxidase I } & $\underline{L} 19185$ & $\underline{\mathrm{P} 32119}$ & $\underline{U 06099}$ & P35704 & 4.9-fold & $2-20$ & 3.9-fold & 21 days \\
\hline & $\times 82321$ & P31945 & & & & & & \\
\hline Platelet-Derived Growth Factor A & $\underline{\times 06374}$ & $\underline{\mathrm{P} 04085}$ & $\underline{\mathrm{L} 06894}$ & $\underline{\mathrm{P} 28576}$ & I.6-fold & $2-6$ & 0.5 -fold & 21 days \\
\hline Matrix Metalloproteinase I4 & $\underline{X 83535}$ & Q92678 & X83537 & Q10739 & 6.9-fold & $2-6$ & 3.3-fold & $24 h-3 d$ \\
\hline Kinase receptor TYRO3 Sky proto-oncogene & D17517 & $\mathrm{Q} 06418$ & D37880 & $\underline{\mathrm{P} 55 \mid 46}$ & 3.I-fold & $9-20$ & 4.0 -fold & $24 h-3 d$ \\
\hline & & & & & & & 0.4 -fold & 21 days \\
\hline CSF-I-Receptor & $\underline{X 03663}$ & $\underline{\mathrm{P} 07333}$ & $\underline{\times 61479}$ & Q00495 & 89.2-fold & $9-20$ & 2.8-fold & 3 days \\
\hline Insulin-like Growth Factor Binding Protein 2 & M35410 & $\underline{\mathrm{P} I 8065}$ & 104486 & $\underline{P I 2843}$ & 79.7-fold & $9-20$ & 2.I-fold & 3 days \\
\hline Mitogen activated kinase $\mathrm{I} / 2$ & M84489 & $\underline{P 28482}$ & $\underline{M 64300}$ & $\underline{\mathrm{P} 27703}$ & 48.6-fold & $9-20$ & 0.3 -fold & 21 days \\
\hline Aquaporin 4 & $\underline{\text { U34846 }}$ & $\underline{P 55087}$ & $\underline{U 14007}$ & $\underline{\mathrm{P}} 47863$ & 18-fold & $9-20$ & 3.2-fold & 3 days \\
\hline erbB2 proto-oncogene Neu proto-oncogene & M95667 & P04626 & $\times 03362$ & $\underline{P 06494}$ & II.2-fold & $9-20$ & 2.7-fold & $12 \mathrm{hrs}$ \\
\hline & $\underline{M I I 730}$ & Q14256 & & & & & & \\
\hline L-type calcium channel $\beta 3$ & $\underline{U 07139}$ & $\underline{P 54284}$ & M8875I & P54287 & 10.3-fold & $9-20$ & 8.6-fold & 21 days \\
\hline Ras-related protein RAB3A & M28210 & $\underline{\mathrm{P} 20336}$ & $\times 06889$ & $\underline{P 05713}$ & 13.9-fold & $9-20$ & 0.3 -fold & 21 days \\
\hline CAMK-II beta & $\underline{\mathrm{U} 50358}$ & Q13554 & MI6II2 & $\underline{P 08413}$ & I.8-fold & $9-20$ & 0.3 -fold & 21 days \\
\hline Growth Factor Receptor-Bound 2 & $\underline{\mathrm{L} 295 \mathrm{II}}$ & Q63057 & D49846 & Q63057 & 19.9-fold & $9-20$ & 2.7-fold & 3 days \\
\hline & M96995 & Q14450 & & Q14450 & & & & \\
\hline Signal Transducer \& Activator of Transcription 3 & $\underline{\mathrm{L} 29277}$ & $\underline{\text { P40763 }}$ & $\underline{X 91810}$ & $\underline{\text { P52631 }}$ & 0.4-fold & $9-20$ & 6.6-fold & $4 h-3 d$ \\
\hline & & & & & & & 0.05 -fold & 21 days \\
\hline Neuronatin & $\underline{\mathrm{U} 25033}$ & Q16517 & $\underline{\cup 08290}$ & Q62649 & II.I-fold & $9-20$ & 0.4-fold & 21 days \\
\hline & & & & $\underline{Q 62663}$ & & & & \\
\hline Glutathione S-Transferase P & $\underline{\times 08058}$ & $\underline{P 09211}$ & $\underline{X 02904}$ & $\underline{\mathrm{P} 04906}$ & 3.I-fold & $9-20$ & 0.1 -fold & $\mathrm{I} \mathrm{hr}$ \\
\hline Glucocorticoid-regulated serine/threonine kinase GSK & A 000512 & 000141 & $\underline{L} 01624$ & Q06226 & 0.6 -fold & $26-37$ & 2.4-fold & 3 days \\
\hline & & & & & & & 0.05 -fold & 21 days \\
\hline Glucose Transporter I & $\underline{\mathrm{K} 03195}$ & $\underline{P I I I 66}$ & MI3979 & $\underline{P I I 167}$ & 0.6 -fold & $26-37$ & II.6-fold & $4 h-21 d$ \\
\hline
\end{tabular}


Table 4: Protein expression in infarcted $(I)$ and peri-infarcted $(P)$ areas (Fold increase compared to contralateral hemisphere)

\begin{tabular}{|c|c|c|c|c|c|c|c|}
\hline \multirow[b]{2}{*}{ Patient no. } & \multirow[b]{2}{*}{ Survival (days) } & \multicolumn{2}{|c|}{ PAKI } & \multicolumn{2}{|c|}{ INII } & \multicolumn{2}{|c|}{ MMPII } \\
\hline & & $P$ & 1 & $P$ & 1 & $P$ & I \\
\hline 1 & 2 & 2.2 & 1.0 & 1.5 & 1.5 & 1.5 & 1.5 \\
\hline 2 & 3 & 3.3 & 4.0 & 0.2 & 0.4 & 1.0 & 1.0 \\
\hline 3 & 3 & 1.0 & 1.0 & 4.2 & 4.3 & 0.7 & 0.7 \\
\hline 4 & 6 & 1.0 & 1.0 & 4.3 & 5.8 & 1.6 & 1.5 \\
\hline 5 & 9 & 1.5 & 0.4 & 3.2 & 3.3 & ND & ND \\
\hline 6 & 15 & 2.3 & 1.5 & 2.8 & 1.0 & 1.7 & 1.6 \\
\hline 7 & 15 & 3.0 & 3.2 & 1.7 & 2.0 & 1.0 & 1.0 \\
\hline 8 & 17 & 1.0 & 1.0 & 1.0 & 1.0 & 1.0 & 1.0 \\
\hline 9 & 20 & 1.0 & 1.0 & 1.0 & 1.0 & 1.0 & 1.0 \\
\hline 10 & 26 & 1.5 & 1.5 & 1.0 & 1.6 & 5.1 & 2.2 \\
\hline 11 & 29 & 1.0 & 1.5 & 2.2 & 2.8 & 1.8 & 3.5 \\
\hline 12 & 37 & 1.5 & 1.0 & 1.7 & 1.7 & 1.0 & 1.5 \\
\hline \multirow[t]{4}{*}{ Total } & Upregulated & 7 & 5 & 8 & 8 & 5 & 6 \\
\hline & Downregulated & 0 & I & 1 & 1 & I & I \\
\hline & No change & 5 & 6 & 3 & 3 & 5 & 4 \\
\hline & No detection & 0 & 0 & 0 & 0 & I & I \\
\hline
\end{tabular}

4Ei), but an increase in cytoplasmic and nuclear staining in neurons occurred following MCAO, in particular at $1 \mathrm{~h}$ and $24 \mathrm{~h}$ (Figure 4Eii). Finally, an increase in PAK1

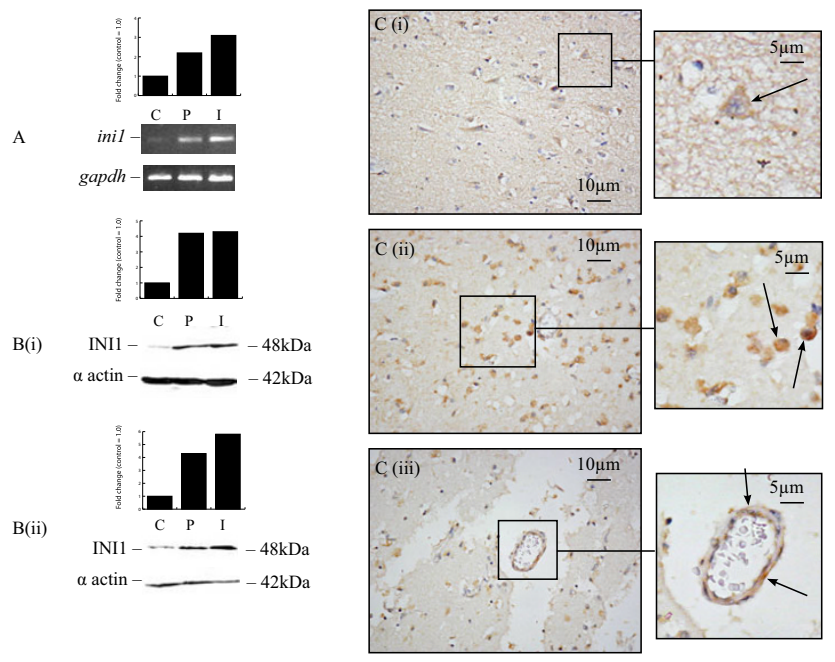

Figure 2

INII expression in human brain following stroke. RTPCR demonstrated an increase in inil mRNA levels in infarcted and peri-infarcted areas of pooled samples from patients surviving from 2 to 6 days following stroke $(A)$. Western blotting showed an increase in protein levels in infarcted and peri-infarcted areas of patients surviving for $3(\mathrm{Bi})$ and 6 (Bii) days following stroke. Moderate INII neuronal staining (arrow) in contralateral areas of a patient surviving for 3 days after stroke $(\mathrm{Ci})$. Strong INII staining in cells (arrows) from infarcted areas of a patient surviving for 15 days after stroke (Cii and iii) (C: Contralateral, P: Peri-infarct, I: Infarct). expression was also seen in human foetal neurons following oxygen-glucose deprivation (Figure 4Fi and 4Fii).

\section{Discussion and Conclusion}

In the human brain, many differentially expressed genes were observed from 2 to 6 days and from 9 to 20 days after stroke, with the majority being upregulated. The number of deregulated genes declined during 26 to 37 days after stroke, indicating that dynamic changes in gene expression occur during the first days to few weeks in the human postischaemic brain. In the rat brain, few differences were observed at 1 hour, while the number of differentially expressed genes steadily increased with time after MCAO, with a peak after 3 days, supporting the concept of active mechanisms initiated during the acute phase after experimental stroke and lasting for several days. The number of upregulated genes gradually increased, peaking at 3 days, while downregulated genes were detected $24 \mathrm{~h}$ after MCAO and increased dramatically until the final measured time-point at 21 days (Figure 1).

The limitations of post-mortem brain samples in cDNA microarray analysis concern the small sample size and potential low quality and the genetic heterogeneity and diversity in terms of age, sex and previous medical history within a group of patients $[28,29]$. We found that analysis of postischaemic gene expression using a cDNA microarray can allow identification of known and novel transcriptional events, molecular participants and signalling mechanisms in cerebral ischaemia as previously suggested, but can also detect differences in gene expression between distinct organisms. 

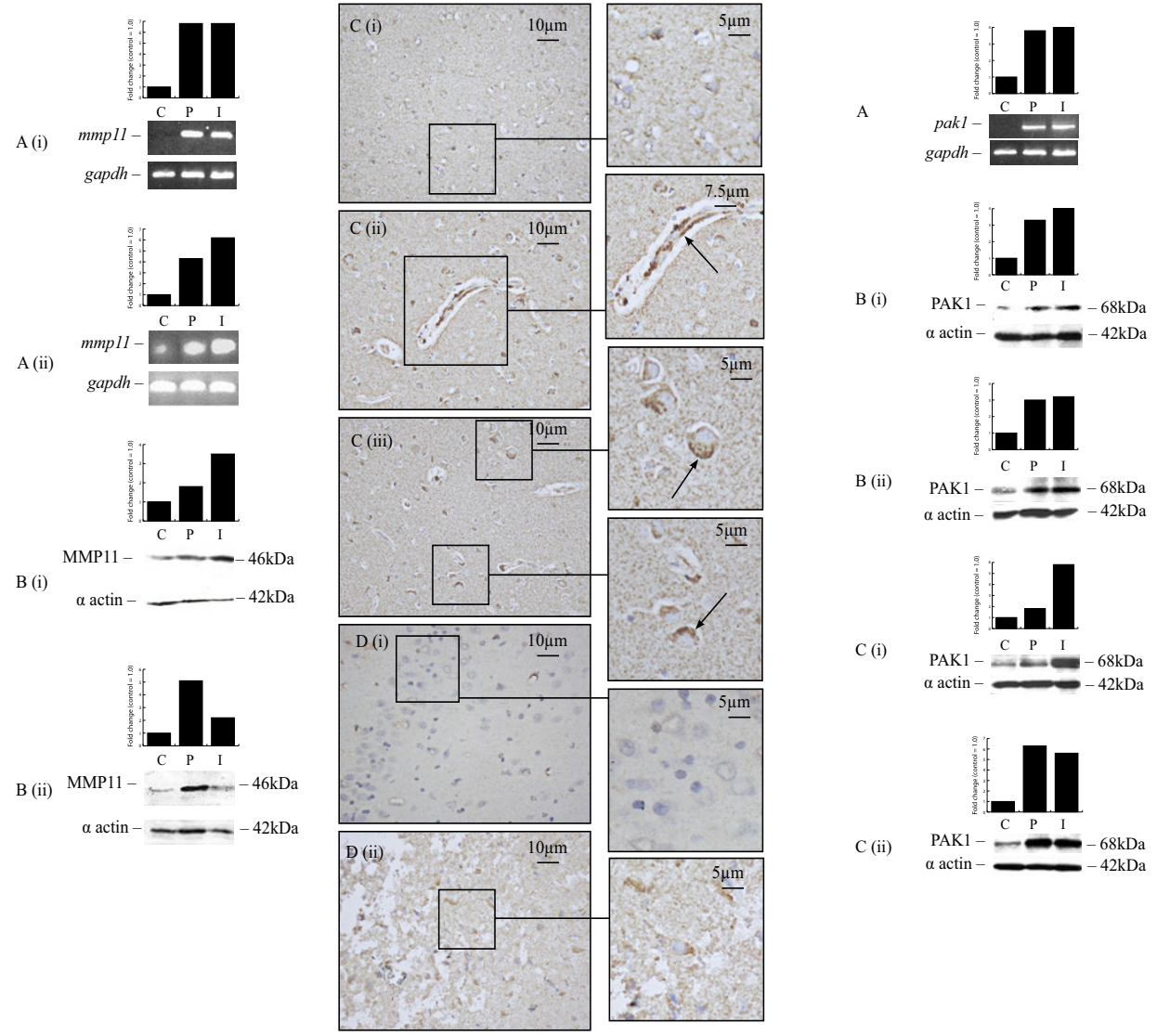

\section{Figure 3}

MMPI I expression in human and rat brain following stroke. RT-PCR demonstrated an increase in MMPII mRNA levels in infarcted and peri-infarcted areas of patients surviving from 2 to 6 days following stroke $(\mathrm{Ai})$ and rats at 3 days after MCAO (Aii). Western blotting demonstrated an increase in protein levels in infarcted and peri-infarcted areas of patients surviving for 29 (Bi) and 26 (Bii) days following stroke. Weak MMPII staining in cells from contralateral areas of a patient surviving for 5 days following stroke $(\mathrm{Ci})$. Blood vessels (Cii) and neurons (Ciii) strongly stained for MMPII in peri-infarcted areas of a patient surviving for 15 days after stroke (arrows). No MMPI I staining observed in contralateral hemisphere of rat brain at I $\mathrm{h}$ after MCAO (Di) but neurons from infarcted areas of rat brain were stained positive for MMPII at 3 days following MCAO (Dii) (C: Contralateral, P: Peri-infarct, I: Infarct).

The present gene expression profile study is the first largescale microarray report showing altered expression of several genes following human stroke. These included genes participating in transcription, apoptosis, inflammation and neuroprotection. Many genes/proteins previously shown to be deregulated following stroke were reported in our study too e.g. IL-10 [30,31], PDGF [32], STAT3 [33,34], MAPK1/2 [35]. To test whether our microarray
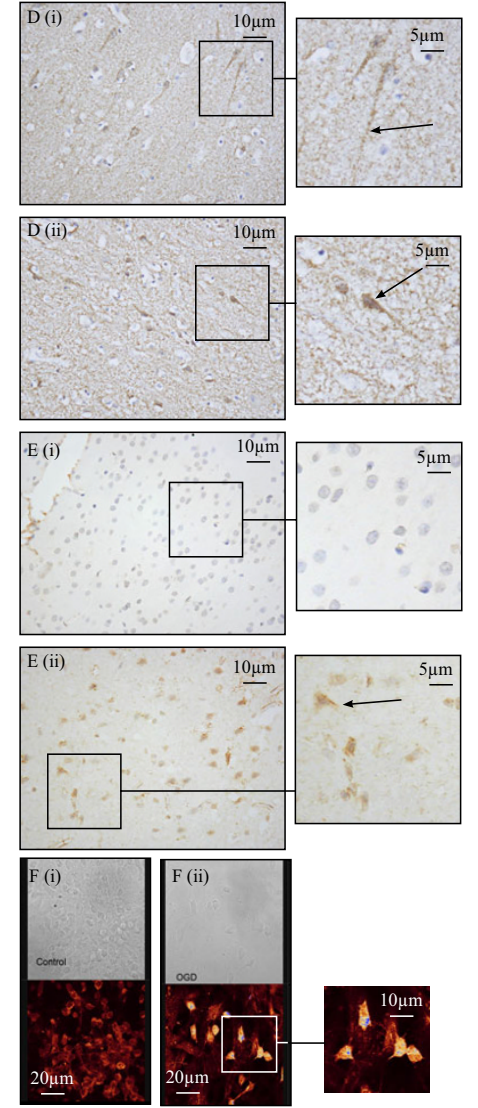

\section{Figure 4}

PAKI expression in human and rat brain following stroke. RT-PCR demonstrated an increase in PAKI mRNA in infarcted and peri-infarcted areas of pooled samples from patients surviving from 2 to 6 days following stroke (A). Western blotting demonstrated an increase in protein levels in infarcted and peri-infarcted areas of patients surviving for 3 (Bi) and I5 (Bii) days following stroke and in rats at $12 \mathrm{~h}(\mathrm{Ci})$ and $24 \mathrm{~h}$ (Cii) following MCAO. Weak neuronal (axonal) staining (arrow) observed in contralateral areas of a patient surviving for 15 days following stroke (Di). Strong PAK I staining in neurons (arrow) and cells with the morphological appearance of glia from infarcted areas of a patient surviving for 3 days following stroke (Dii). No staining observed in contralateral areas of rat brain at $24 \mathrm{~h}$ following MCAO (Ei) while strong PAKI staining was seen in neurons (arrow) and cells with the morphological appearance of glia from infarcted areas of rat brain I $\mathrm{h}$ following MCAO (Eii). Stronger PAKI immunofluorescent staining was seen in HFN following OGD (Fii) compared to control (Fi) (C: Contralateral, P: Peri-infarct, I: Infarct).

analysis could predict novel candidate genes involved in the cerebral response to ischaemia with possible functional importance and significance in stroke-induced neuronal damage, we measured protein expression and 
cellular localisation for three induced genes, INI1, PAK1 and MMP11. They were chosen because they showed at least 2-fold mRNA induction and there was no prior published evidence implicating them in human cerebral ischaemia.

PAK1 is a downstream Rac effector and a major cyclindependent kinase 5 (Cdk5) substrate and target that colocalizes with p35/Cdk5 at neuronal peripheries. P35/ Cdk5 causes PAK1 hyperphosphorylation, which results in PAK1 down-regulation and is likely to have an impact on the dynamics of the reorganization of the actin cytoskeleton in neurons during dendrite development [36]. Based on this evidence, these authors proposed the existence of a neuron-specific signalling complex involving Cdk5/p35-PAK1 that inhibits PAK1 activity in neurons. We have recently provided evidence for a potential role of $\mathrm{Cdk} 5 / \mathrm{p} 35$ in the response to ischaemic injury as we showed association of Cdk5 with nuclear damage, by demonstrating co-expression of Cdk5 in TUNEL-positive neurons following human stroke and in propidium iodide-positive human foetal neurons following OGD [37]. Here, we have reported for the first time an upregulation in PAK1 protein levels in human and rat brain samples following MCAO and in HFN following oxygenglucose deprivation. Although in the animal model PAK1 protein levels returned to normal 3 days following stroke, some patients showed elevated levels for PAK1 at later time-points too. In both human and the animal model, neurons were the predominant type of cells stained positive for PAK1.

MMP11 or stromelysin-3 (ST3), first isolated as a breast cancer-associated protease, is not expressed in the majority of normal adult organs but is expressed during a number of pathological processes, including wound healing and atherosclerotic lesions [38,39]. Although other metalloproteinases have been studied extensively following stroke $[40,41]$, there is no report of the expression of MMP11 following stroke in vivo or in vitro. Here we report an increase in protein levels of MMP11 following stroke in both human and rat brain, although the increase seen in man remained elevated much longer. Although MMP11 shares many similarities with other MMPs, it also differs in that it exhibits anti-apoptotic properties, a first-known activity for a MMP [42]. Moreover, although it is expressed in many processes involving tissue remodelling, cell migration and cell death, the pathways through which it participates in pathogenesis remain unclear, largely due to the lack of information on its substrates in vivo [43].

INI1 is a tumour suppressor gene, thought to exert its tumour suppressor function by mediating cell cycle arrest [44]. It was initially identified as a human homolog of yeast transcriptional activator SNF5 that binds to the HIV-
1 integrase and stimulates its DNA-joining activity [45]. Brains of AIDS patients had been shown to manifest neuronal injury and apoptotic-like cell death raising the question about the way HIV-1 resulted in neuronal damage, since neurons themselves are very rarely infected by the virus [46]. Adler et al. [47] also reported an association of the human SNF5/INI1 protein with growth arrest and DNA damage-inducible protein 34 (GADD34) that mediates growth arrest and apoptosis in response to stress signals $[48,49]$. Our study is the first to suggest a potential role for INI1 in pathways activated after stroke with a possible role in brain injury. However, in the animal model study, INI1 levels remained unchanged following stroke. The reason for this discrepancy warrants further studies.

Many experimental trials of stroke therapies have failed to translate to human clinical trials and one possible way to improve the success rate can be through comparative genomics. As it has been recently commented, it is very surprising that the exciting developments observed in basic and clinical stroke research over the past two decades have occurred in parallel, with too little direct translation between bench and bedside [50]. Here, we have provided substantial evidence that, although the available animal models of MCAO may well be suitable to study the pathophysiological changes following the occlusion of a cerebral vessel, they may not entirely reflect the pathophysiological process through which stroke evolves in humans. The species difference is one of the main reasons accounting for the lack of success of bench to bedside translation in the stroke area. Limitations of our study include the fact that early acute phase changes in gene expression may have been missed since genes induced and returning to normal during the first 48 hours postischaemia in man could not have been detected. Moreover, since we analyzed pooled RNA samples, small changes in gene expression occurring in a minority of the samples may have been missed. However, there was only a small overlap of our results with prior studies in experimental stroke involving brain tissue, and the successful identification of novel ischaemia-related genes reported here suggests that performing a further study using whole genome microarrays would be valuable.

\section{Methods}

\section{Human brain autopsy specimens}

Human brain tissue samples were obtained from 12 patients who died from acute ischaemic stroke, with the approval of the local Ethics Committee and Brain Bank at the Department of Neuropathology, Collegium Medicum, Jagiellonian University, Krakow, Poland. All patients were admitted with large middle cerebral artery strokes confirmed by CT-scan or MRI. The patients, 10 male and 2 female, were aged between 51 and 86 years and had survived between 2-37 days following ischaemic stroke 
(Table 2). Routine blood parameters were determined on admission. Full clinical examinations, including $\mathrm{NIH}$ Stroke Scale, were also carried out on admission. Excluded from the study were patients with recent history of head trauma, major cardiac, renal, hepatic or cancerous disease and obvious signs of infection after admission. Immediately after death the body was put in a cold chamber and tissue was collected within $6 \mathrm{~h}$ of death. Tissue samples were taken from infarct and peri-infarcted zones while controls were obtained from the contralateral hemisphere at the same time. The peri-infarcted areas were defined in tissue sections as the tissue immediately surrounding the infarcted core which contained some necrotic cells and showed evidence of tissue disorganisation confirmed by histology. Sections were stained with 2,3,5-triphenyltetrazolium chloride which stains active mitochondria pink; therefore, non stained areas represented stroke affected cortical regions (data not included). Tissue specimens were immediately frozen in liquid nitrogen, kept at $-70^{\circ} \mathrm{C}$ and a portion of each sample was processed for histology and stained with haematoxylin and eosin to determine tissue morphology [51].

\section{Rat middle cerebral artery occlusion}

Stroke experiments were performed on female SpragueDawley rats (weight: 230-270 g) as they suffer less than male during ischaemia. Cerebral ischaemia was produced using a modified method of Baron [52] by distal, permanent occlusion of the MCA by electrocautery as described elsewhere $[53,54]$. The mortality in this model is very low. Sets of six animals ( 3 for morphological studies and 3 pooled together) for each time-point were sacrificed at 1 h, 4 h, 12 h, $24 \mathrm{~h}$ and 3, 7 and 21 days.

\section{In vitro oxygen-glucose deprivation (OGD)}

Human brain microvascular endothelial cells (HBMEC) were obtained from TCS CellWorks (Buckingham, UK) and cultured according to the supplier's instructions. Human foetal (cerebral cortical) neurons (HFN) were extracted and cultured with permission from the Local Ethics Committee. Brain tissue from foetus specimens of 14-19 weeks gestational age, legally aborted and with the appropriate written consent, were collected in cold preservation medium and cells were isolated and cultured as described elsewhere [55]. For OGD experiments, the culture medium was replaced by glucose-free medium containing $2 \%$ foetal bovine serum (TCS CellWorks, Buckingham, UK) and cells were cultured at $37^{\circ} \mathrm{C}$ in a humidified chamber with $94 \% \mathrm{~N}_{2}, 1 \% \mathrm{O}_{2}$, and $5 \% \mathrm{CO}_{2}$ for $6 \mathrm{~h}$ (HBMEC) or $95 \% \mathrm{~N}_{2}$ and $5 \% \mathrm{CO}_{2}$ for $14 \mathrm{~h}$ (HFN) followed by $24 \mathrm{~h}$ reperfusion in fresh medium containing $4.5 \mathrm{~g} / \mathrm{l}$ glucose. This resulted in approximately 30\% of cells undergoing apoptosis after OGD and 60\% following reoxygenation, as determined from our pilot studies. Cells cultured in normoxic conditions without glucose depriva- tion were used as controls. In some experiments, propidium iodide $(10 \mu \mathrm{g} / \mathrm{ml})$ was added to the cultures $1 \mathrm{~h}$ before the end of the experiment to stain dead and dying cells.

\section{cDNA microarrays}

We established mRNA expression profiles of the damaged brain tissues between 2 to 6 days, 9 to 20 days, and 26 to 37 days after stroke in human patients and 1, 4, 12, 24 hours and 3, 7 and 21 days after the ischaemic insult in rats. The corresponding samples from the non-ischemic control hemisphere were used to measure the normal mRNA abundance of the modulated genes in each tissue at each time point. RNA from three stroke patients was pooled for each patient survival group while RNA from three MCAO rats was also pooled at each time-point to improve yields in preparation of poly $\mathrm{A}^{+} \mathrm{RNA}$. Although pooling was previously thought to affect data quality, Kendziorski et al. [56] have recently shown that inference was not adversely affected by pooling. The different patient groups were selected to match the three physiological stages following stroke i.e. the inflammatory (lasting up to a maximum of 5-6 days), the proliferative (lasting up to three weeks following stroke) and the remodelling/ maturation (starting during the third or fourth week).

RNA was extracted according to the manufacturer's protocols (BD Biosciences, Oxfordshire, UK) and its quality was measured spectrophotometically. The protocol recommended by Clontech in their Atlas 1.2 microarray kit was used without any modification. Briefly, RNA was reversetranscribed to cDNA, ${ }^{32} \mathrm{P}$-labelled and applied to the array for overnight hybridisation at $68^{\circ} \mathrm{C}$. Following washing, the array was exposed to a phosphorimaging plate for 12-72 hours and data analysis was performed using the AtlasImage 1.5 software. The results were normalized using two housekeeping genes, ubiquitin and glyceraldehyde 3-phosphate dehydrogenase (GAPDH). As in the majority of microarray studies mentioned before, only those genes upregulated $>2$-fold or downregulated $<0.5$ fold were counted as deregulated and taken into consideration. The microarray data are available in Gene Expression Omnibus under the accession number GSE9391.

\section{Reverse Transcription-Polymerase Chain Reaction (RT- PCR)}

Gene expression was examined by semi-quantitative RTPCR with standard reaction conditions of a $10 \mathrm{~min}$ denaturation at $94^{\circ} \mathrm{C}$, followed by 35 cycles of $1 \mathrm{~min}$ at $94^{\circ} \mathrm{C}$, $1 \mathrm{~min}$ at primer-specific annealing temperatures (Table 5) and $1 \mathrm{~min}$ at $72^{\circ} \mathrm{C}$ and a final $10 \mathrm{~min}$ extension step at $72^{\circ} \mathrm{C}$. Samples without cDNA were used as negative controls and the products were visualized by agarose gel electrophoresis $(1.5 \% \mathrm{w} / \mathrm{v})$ and DNA stained with ethidium bromide $(10 \mathrm{mg} / \mathrm{ml})$. All experiments were carried out at 
Table 5: Primer sequences

\begin{tabular}{|c|c|c|c|}
\hline Gene & Species & Primer Sequence & T annealing \\
\hline$m m p / I$ & Human & 5'-TAAAGGTATGGAGCGATGTGAC-3' (forward) & $58^{\circ} \mathrm{C}$ \\
\hline$m m p l I$ & & 5'-TGGGTAGCGAAAGGTGTAGAAG-3' (reverse) & \\
\hline$m m p / I$ & Rat & 5'-GATGGAGGCCAGCTAGTCAG-3' (forward) & $60^{\circ} \mathrm{C}$ \\
\hline$m m p l I$ & & 5'-ATGGTACATGACCACGCAGA-3' (reverse) & \\
\hline inil & Human & 5'-ACCCTGTCCAACAGCTCCCA-3' (forward) & $64^{\circ} \mathrm{C}$ \\
\hline inil & & 5'-GGCCCAATCTTCTGAGATGC-3' (reverse) & \\
\hline inil & Rat & 5'-CCTGGGGCTCCTATACAAAA-3' (forward) & $60^{\circ} \mathrm{C}$ \\
\hline inil & & 5'-CCATGACCGAGCAAATGAC-3' (reverse) & \\
\hline pakl & Human & 5'-GCTGTTCTGGATGTGTTGGA-3' (forward) & $60^{\circ} \mathrm{C}$ \\
\hline pakl & & 5'-TCTGCTCTGGGGTTATCTGTG-3' (reverse) & \\
\hline pakl & Rat & 5'-AGCAAAAGAGGCAACCAAGA-3' (forward) & $60^{\circ} \mathrm{C}$ \\
\hline pakl & & 5'-GGGTAAGGAATGGGATGGTT-3' (reverse) & \\
\hline gapdh & Human & 5'-ATGATCTTGAGGCTGTTG-3' (forward) & $58^{\circ} \mathrm{C}$ \\
\hline gapdh & & 5'-CTCAGACACCATGGGGAA-3' (reverse) & \\
\hline
\end{tabular}

$25,30,35$ and 40 cycles to ensure the semi-quantitative nature of the results. The results were normalized using housekeeping gene GAPDH and semi-quantitavely analyzed using Scion Imaging Software version 4.02 (Scion Corporation, Maryland, USA). Sense and antisense oligonucleotide primers containing 18-27 nucleotides based on previously reported mRNA sequences in the GenBank depository were designed with the aid of the Primer3 Output Program (Version 0.2). InVitrogen plc. (Paisley, UK) synthesized the primer sets (Table 5).

\section{Protein extraction and Western blotting}

Proteins were extracted from tissues and the protein concentration of each sample was determined using the BioRad assay. For Western blotting, $10 \mu \mathrm{g}$ of protein were separated by SDS-PAGE ( $13 \% \mathrm{w} / \mathrm{v})$ and the proteins were electro-blotted onto nitrocellulose filters as described previously [57]. Filters were blocked in $1 \% \mathrm{w} / \mathrm{v}$ bovine serum albumin (BSA) in Tris-buffered saline Tween (TBS Tween) and stained overnight at $4{ }^{\circ} \mathrm{C}$ with antibodies to the following proteins (obtained from Autogen Bioclear, Wiltshire, UK, unless stated otherwise) diluted in 1\% BSA: MMP11 (CalBiochem; 1:500), PAK1 (1:500), INI1 (1:500), and $\alpha$-actin (Sigma, 1:1000) used as a loading control. Membranes were washed in TBS-Tween before staining with the appropriate peroxidase-conjugated secondary antibody, diluted 1:1000 in 5\% w/v milk in TBSTween for $\mathrm{l} \mathrm{h}$. Blots were developed with the ECL detection system (Amersham, UK). The relative intensities of the bands were measured in an LKB densitometer. Results are semi-quantitative and are given as a numerical (fold) change compared to the control (contralateral tissue) which was given an arbitrary value of 1.0. All experiments were performed twice and a representative example of patient(s) showing an increase in protein expression is given.

\section{Immunohistochemistry/Immunofluorescence}

Paraffin-embedded tissue samples were processed and serial $5 \mu \mathrm{m}$ sections were cut. The Avidin-Biotin Peroxidase (ABC Vectastain kit, Vector Laboratories, Peterborough, UK) method was used and antibodies to MMP11, PAK1 and INI1 were used at a dilution of 1:50. Paraffinembedded sections were deparaffinized, rehydrated and boiled for $10 \mathrm{~min}$ in an antigen unmasking solution of concentrated citric acid pH 6.0 as described elsewhere [57]. Slides were incubated in $0.5 \% \mathrm{v} / \mathrm{v}_{2} \mathrm{O}_{2}$ in methanol for $30 \mathrm{~min}$, with normal serum for $20 \mathrm{~min}$ and then with a primary antibody (diluted in normal serum) for $30 \mathrm{~min}$, followed by 30-min incubation with biotinylated secondary antibody (diluted 1:50) and finally with ABC complex (diluted 1:50) for $30 \mathrm{~min}$ at RT. Staining was completed after incubation with DAB substrate chromogen solution for 3-10 min. Slides were counterstained with haematoxylin, dehydrated, cleared and mounted in DPX. For immunofluorescence, cultured cells were fixed in $4 \%$ paraformaldehyde for $20 \mathrm{~min}$, permeabilized with $0.2 \%$ Triton $\times 100$ for 10 min, blocked with normal serum and stained with the primary antibody as above, followed by $1 \mathrm{~h}$ incubation with Alexa-fluor conjugated dye at RT. Negative control slides were performed in parallel, where primary antibody was replaced with washing buffer and processed as above (data not included).

\section{Abbreviations}

GAPDH: glyceraldehyde 3-phosphate dehydrogenase; HBMEC: human brain microvascular endothelial cells; HFN: human foetal neurons; INI1: integrase interactor 1; MCAO: middle cerebral artery occlusion; MMP11: matrix metalloproteinase; OGD: oxygen-glucose deprivation; PAK1: p21-activated kinase 1. 


\section{Authors' contributions}

NM carried out the human studies and drafted the manuscript. MOS carried out the experimental work in rats. JK and FR provided the material for the study. RP and CS carried out the in vitro work. QW participated in the analysis of the microarray results. MS performed the statistical analysis. JG, PK and SK participated in the design and coordination of the study and helped to draft the manuscript. MAS conceived of the study, and directed the research project. All authors read and approved the final manuscript.

\section{Acknowledgements}

This work was supported by the Higher Education Funding Council for England (HEFCE) and the Research Institute for Health and Social Change (RIHSC). We also thank Mick Hoult for his assistance in the preparation of this manuscript.

\section{References}

I. Mitsios N, Gaffney J, Kumar P, Krupinski J, Kumar S, Slevin M: Pathophysiology of acute ischaemic stroke: An analysis of common signalling mechanisms and identification of new molecular targets. Pathobiology 2006, 73(4):I59-I75.

2. Slevin M, Krupinski J, Kumar P, Gaffney J, Kumar S: Gene activation and protein expression following ischaemic stroke: strategies towards neuroprotection. Journal Of Cellular And Molecular Medicine 2005, 9(I):85-102.

3. Schaller B, Graf R: Cerebral ischemia and reperfusion: The pathophysiologic concept as a basis for clinical therapy. Journal Of Cerebral Blood Flow And Metabolism 2004, 24(4):35I-37I.

4. Slevin M, Kumar P, Gaffney J, Kumar S, Krupinski J: Can angiogenesis be exploited to improve stroke outcome? Mechanisms and therapeutic potential. Clinical Science 2006, I I I(3): I7I-I83.

5. Longa EZ, Weinstein PR, Carlson S, Cummins R: Reversible Middle Cerebral-Artery Occlusion Without Craniectomy In Rats. Stroke 1989, 20(I):84-9I.

6. Hasselblatt M, Jeibmann A, Riesmeier B, Maintz D, Schabitz WR: Granulocyte-colony stimulating factor (G-CSF) and G-CSF receptor expression in human ischemic stroke. Acta Neuropathologica 2007, I I3( I):45-5 I.

7. Rosell A, Ortega-Aznar A, Alvarez-Sabin J, Fernandez-Cadenas I, Ribo M, Molina CA, Lo EH, Montaner J: Increased brain expression of matrix metalloproteinase-9 after ischemic and hemorrhagic human stroke. Stroke 2006, 37(6): I399- I406.

8. Kim YD, Sohn NW, Kang CH, Soh Y: DNA array reveals altered gene expression in response to focal cerebral ischemia. Brain Research Bulletin 2002, 58(5):491-498.

9. Rao VLR, Bowen KK, Dhodda VK, Song GQ, Franklin JL, Gavva NR, Dempsey RJ: Gene expression analysis of spontaneously hypertensive rat cerebral cortex following transient focal cerebral ischemia. Journal of Neurochemistry 2002, 83(5): $1072-1086$.

10. Roth A, Gill R, Certa U: Temporal and spatial gene expression patterns after experimental stroke in a rat model and characterization of $\mathrm{PC4}$, a potential regulator of transcription. Molecular And Cellular Neuroscience 2003, 22(3):353-364.

II. Lippoldt A, Reichel A, Moenning U: Progress in the identification of stroke-related genes - Emerging new possibilities to develop concepts in stroke therapy. Cns Drugs 2005, I 9(I 0):82I-832

12. Ford G, Xu ZF, Gates A, Jiang J, Ford BD: Expression Analysis Systematic Explorer (EASE) analysis reveals differential gene expression in permanent and transient focal stroke rat models. Brain Research 2006, I07I(I):226-236.

13. Jin KL, Mao XO, Eshoo MW, Nagayama T, Minami M, Simon RP, Greenberg DA: Microarray analysis of hippocampal gene expression in global cerebral ischemia. Annals of Neurology 200I, 50(I):93-I03.

14. Kim JB, Piao CS, Lee KW, Han PL, Ahn JI, Lee YS, Lee JK: Delayed genomic responses to transient middle cerebral artery occlusion in the rat. Journal Of Neurochemistry 2004, 89(5): $|27|-\mid 282$

15. Lu XCM, Williams AJ, Yao C, Berti R, Hartings JA, Whipple R, Vahey MT, Polavarapu RG, Woller KL, Tortella FC, Dave JR: Microarray analysis of acute and delayed gene expression profile in rats after focal ischemic brain injury and reperfusion. Journal of Neuroscience Research 2004, 77(6):843-857.

16. Schmidt-Kastner R, Zhang BT, Belayev L, Khoutorova L, Amin R, Busto R, Ginsberg MD: DNA microarray analysis of cortical gene expression during early recirculation after focal brain ischemia in rat. Molecular Brain Research 2002, I 08(1-2):81-93.

17. Soriano MA, Tessier M, Certa U, Gill R: Parallel gene expression monitoring using oligonucleotide probe arrays of multiple transcripts with an animal model of focal ischemia. Journal of Cerebral Blood Flow And Metabolism 2000, 20(7): I045-1055.

18. Tang Y, Lu AG, Aronow BJ, Wagner KR, Sharp FR: Genomic responses of the brain to ischemic stroke, intracerebral haemorrhage, kainate seizures, hypoglycemia, and hypoxia. European Journal Of Neuroscience 2002, I5(1 2): I 937- 1952.

19. Moore DF, Li H, Jeffries N, Wright V, Cooper RA, Elkahloun A, Gelderman MP, Zudaire E, Blevins G, Yu H, Goldin E, Baird AE: Using peripheral blood mononuclear cells to determine a gene expression profile of acute ischemic stroke - A pilot investigation. Circulation 2005, I I I (2):2 I 2-22I.

20. Tang Y, Xu HC, Du XL, Lit L, Walker W, Lu AG, Ran RQ, Gregg JP, Reilly M, Pancioli A, Khoury JC, Sauerbeck LR, Carrozzella JA, Spilker J, Clark J, Wagner KR, Jauch EC, Chang DJ, Verro P, Broderick JP, Sharp FR: Gene expression in blood changes rapidly in neutrophils and monocytes after ischemic stroke in humans: a microarray study. Journal Of Cerebral Blood Flow And Metabolism 2006, 26(8): I089-I I02.

21. Hynd MR, Lewohl JM, Scott HL, Dodd PR: Biochemical and molecular studies using human autopsy brain tissue. Journal Of Neurochemistry 2003, 85(3):543-562.

22. Schramm M, Falkai P, Tepest R, Schneider-Axmann T, Przkora R, Waha A, Pietsch T, Bonte W, Bayer TA: Stability of RNA transcripts in post-mortem psychiatric brains. Journal Of Neural Transmission 1999, 106(3-4):329-335.

23. Sairanen T, Karjalainen-Lindsberg ML, Paetau A, ljas P, Lindsberg PJ: Apoptosis dominant in the periinfarct area of human ischaemic stroke - a possible target of antiapoptotic treatments. Brain 2006, I 29:189-199.

24. Sairanen T, Ristimaki A, Karjalainen-Lindsberg ML, Paetau A, Kaste M, Lindsberg PJ: Cyclooxygenase- 2 is induced globally in infarcted human brain. Annals Of Neurology 1998, 43(6):738-747.

25. Castensson A, Emilsson L, Preece P, Jazin E: High-resolution quantification of specific mRNA levels in human brain autopsies and biopsies. Genome Research 2000, I0(8): I2I 19-1229.

26. Almeida A, Thiery JP, Magdelenat $H$, Radvanyi F: Gene expression analysis by real-time reverse transcription polymerase chain reaction: influence of tissue handling. Analytical Biochemistry 2004, 328(2): I0I-108.

27. Vikman P, Edvinsson L: Gene expression profiling in the human middle cerebral artery after cerebral ischemia. European Journal Of Neurology 2006, I 3( I 2): I 324- I 332.

28. Iwamoto K, Kato T: Gene expression profiling in schizophrenia and related mental disorders. Neuroscientist 2006, I 2(4):349-36I.

29. Mirnics K, Pevsner J: Progress in the use of microarray technology to study the neurobiology of disease. Nature Neuroscience 2004, 7(5):434-439.

30. Perini F, Morra M, Alecci M, Galloni E, Marchi M, Toso V: Temporal profile of serum anti-inflammatory and pro-inflammatory interleukins in acute ischemic stroke patients. Neurological Sciences 200I, 22(4):289-296.

31. Tarkowski E, Rosengren L, Blomstrand C, Wikkelso C, Jensen C, Ekholm S, Tarkowski A: Intrathecal release of pro- and antiinflammatory cytokines during stroke. Clinical And Experimental Immunology 1997, I I 0(3):492-499.

32. Krupinski J, Issa R, Bujny T, Slevin M, Kumar P, Kumar S, Kaluza J: A putative role for platelet-derived growth factor in angiogenesis and neuroprotection after ischemic stroke in humans. Stroke 1997, 28(3):564-573.

33. Choi JS, Kim SY, Cha JH, Choi YS, Sung KW, Oh ST, Kim ON, Chung $\mathrm{JW}$, Chun MH, Lee SB, Lee MY: Upregulation of gp I30 and 
STAT3 activation in the rat hippocampus following transient forebrain ischemia. Glia 2003, 4I(3):237-246.

34. Justicia C, Gabriel C, Planas AM: Activation of the JAK/STAT pathway following transient focal cerebral ischemia: Signaling through Jakl and Stat3 in astrocytes. Glia 2000, 30(3):253-270.

35. Slevin M, Krupinski J, Slowik A, Rubio F, Szczudlik A, Gaffney J: Activation of MAP kinase (ERK-I/ERK-2), tyrosine kinase and VEGF in the human brain following acute ischaemic stroke. Neuroreport 2000, I I(I 2):2759-2764.

36. Nikolic M, Chou MM, Lu WG, Mayer BJ, Tsai LH: The p35/Cdk5 kinase is a neuron-specific Rac effector that inhibits Pakl activity. Nature 1998, 395(6698): 194-198.

37. Mitsios N, Pennucci R, Krupinski J, Sanfeliu C, Gaffney J, Kumar P, Kumar S, Juan-Babot O, Slevin M: Expression of cyclin-dependent kinase 5 mRNA and protein in the human brain following acute ischemic stroke. Brain Pathology 2007, I 7(I): I I-23.

38. Schonbeck U, Mach F, Sukhova GK, Atkinson E, Levesque E, Herman $M$, Graber $P$, Basset $P$, Libby $P$ : Expression of stromelysin-3 in atherosclerotic lesions: Regulation via CD40-CD40 ligand signaling in vitro and in vivo. Journal Of Experimental Medicine 1999, 189(5):843-853.

39. Wolf C, Chenard MP, Degrossouvre PD, Bellocq JP, Chambon P, Basset P: Breast-Cancer Associated Stromelysin-3 Gene Is Expressed In Basal-Cell Carcinoma And During Cutaneous Wound-Healing. Journal Of Investigative Dermatology 1992, 99(6):870-872.

40. Montaner J, Alvarez-Sabin J, Molina C, Angles A, Abilleira S, Arenillas J, Gonzalez MA, Monasterio J: Matrix metalloproteinase expression after human cardioembolic stroke - Temporal profile and relation to neurological impairment. Stroke 200I, 32(8): 1759-1766.

41. Montaner J, Alvarez-Sabin J, Molina CA, Angles A, Abilleira S, Arenillas J. Monasterio J: Matrix metalloproteinase expression is related to hemorrhagic transformation after cardioembolic stroke. Stroke 200I, 32(I 2):2762-2767.

42. Matziari M, Dive V, Yiotakis A: Matrix metalloproteinase II (MMP-I I; stromelysin-3) and synthetic inhibitors. Medicinal Research Reviews 2007, 10.1002/med.20066:.

43. Wei L, Shi YB: Matrix metalloproteinase stromelysin-3 in development and pathogenesis. Histology And Histopathology 2005, 20(I):177-185.

44. Zhang ZK, Davies KP, Allen J, Zhu L, Pestell RG, Zagzag D, Kalpana GV: Cell cycle arrest and repression of cyclin DI transcription by INII/hSNF5. Molecular And Cellular Biology 2002, 22(16):5975-5988.

45. Kalpana GV, Marmon S, Wang WD, Crabtree GR, Goff SP: Binding And Stimulation Of Hiv-I Integrase By A Human Homolog Of Yeast Transcription Factor Snf5. Science 1994, 266(5 | 93):2002-2006.

46. Lipton SA: Neuronal injury associated with HIV-I: Approaches to treatment. Annual Review Of Pharmacology And Toxicology 1998, 38:159-177.

47. Adler HT, Chinery R, Wu DY, Kussick SJ, Payne JM, Fornace AJ, Tkachuk DC: Leukemic HRX fusion proteins inhibit GADD34 induced apoptosis and associate with the GADD34 and hSNF5/INII proteins. Molecular And Cellular Biology 1999, | 9(10):7050-7060.

48. Hollander MC, Sheikh MS, Yu K, Zhan QM, Iglesias M, Woodworth C, Fornace AJ: Activation of Gadd34 by diverse apoptotic signals and suppression of its growth inhibitory effects by apoptotic inhibitors. International Journal Of Cancer 200I, 96(I):22-3I.

49. Hollander MC, Zhan QM, Bae I, Fornace AJ: Mammalian GADD34, an apoptosis- and DNA damage-inducible gene. Journal Of Biological Chemistry 1997, 272(21):|373|-13737.

50. Dirnagl U: Bench to bedside: the quest for quality in experimental stroke research. Journal Of Cerebral Blood Flow And Metabolism 2006, 26(I 2): : 465-I478.

51. Eke A, Conger KA, Anderson M, Garcia JH: Histologic Assessment Of Neurons In Rat Models Of Cerebral-Ischemia. Stroke 1990, 21(2):299-304.

52. Baron JC: Perfusion thresholds in human cerebral ischemia: Historical perspective and therapeutic implications. Cerebrovascular Diseases 2001, I I:2-8.
53. Krupinski J, Lopez E, Marti E, Ferrer I: Expression of caspases and their substrates in the rat model of focal cerebral ischemia. Neurobiology Of Disease 2000, 7(4):332-342.

54. Krupinski J, Slevin M, Marti E, Catena E, Rubio F, Gaffney J: Timecourse phosphorylation of the mitogen activated protein (MAP) kinase group of signalling proteins and related molecules following middle cerebral artery occlusion (MCAO) in rats. Neuropathology And Applied Neurobiology 2003, 29(2): I 44-I58.

55. Cristofol RM, Gasso S, Vilchez D, Pertusa M, Rodriguez-Farre E, Sanfeliu C: Neurotoxic effects of trimethyltin and triethyltin on human fetal neuron and astrocyte cultures: A comparative study with rat neuronal cultures and human cell lines. Toxicology Letters 2004, I 52(I):35-46.

56. Kendziorski C, Irizarry RA, Chen KS, Haag JD, Gould MN: On the utility of pooling biological samples in microarray experiments. Proceedings Of The National Academy Of Sciences Of The United States Of America 2005, I 02( 1 2):4252-4257.

57. Mitsios N, Gaffney J, Krupinski J, Mathias R, Wang QY, Hayward S, Rubio F, Kumar P, Kumar S, Slevin M: Expression of signaling molecules associated with apoptosis in human ischemic stroke tissue. Cell Biochemistry And Biophysics 2007, 47(I):73-85.
Publish with BioMed Central and every scientist can read your work free of charge

"BioMed Central will be the most significant development for disseminating the results of biomedical research in our lifetime. "

Sir Paul Nurse, Cancer Research UK

Your research papers will be:

- available free of charge to the entire biomedical community

- peer reviewed and published immediately upon acceptance

- cited in PubMed and archived on PubMed Central

- yours - you keep the copyright

Submit your manuscript here:

http://www.biomedcentral.com/info/publishing_adv.asp
BioMedcentral 